\title{
Quadratus Lumborum Block for Incarcerated Hernia Repair in a Multi-Morbid Elderly Patient: A Case Report
}

\author{
Alessandro De Cassai*, Tommaso Tonetti and Carlo Ori
}

Department of Medicine - DIMED, Section of Anesthesiology and Intensive Care, University of Padova, Italy

Submission: March 28, 2018; Published: May 24, 2018

*Corresponding author: Alessandro De Cassai, Department of Medicine - DIMED, Section of Anesthesiology and Intensive Care, University of Padova, Via V. Gallucci, 13, 35121 Padova, Italy, Tel: +39-049-8213090; Email: alessandro.decassai@gmail.com

\section{Introduction}

We report here the case of a 91 years old male patient who presented to our emergency department for lower abdominal pain persisting for two days. Physical examination deposed for left inguinal incarcerated hernia and the surgeon indicated urgent surgical repair. The patient had a history of post-infarctual dilated cardiomyopathy with hypokinesia of the inferior and the lateral left ventricular wall with reduction of ejection fraction (33\%), triple PCI (seventeen years ago), pace-maker implantation for a third degree atrioventricular block, severe pulmonary hypertension (echocardiography-derived systolic pulmonary artery pressure of $70 \mathrm{mmHg}$ ), severe mitral valve insufficiency and third stage chronic kidney disease (CKD).

He was hemodynamically stable and the routine blood exams showed only an elevation of urea and creatinine consistent with the patient's CKD; all other laboratory values, including blood cell count and coagulation profile, were normal. An anesthesiological written informed consent was then acquired.

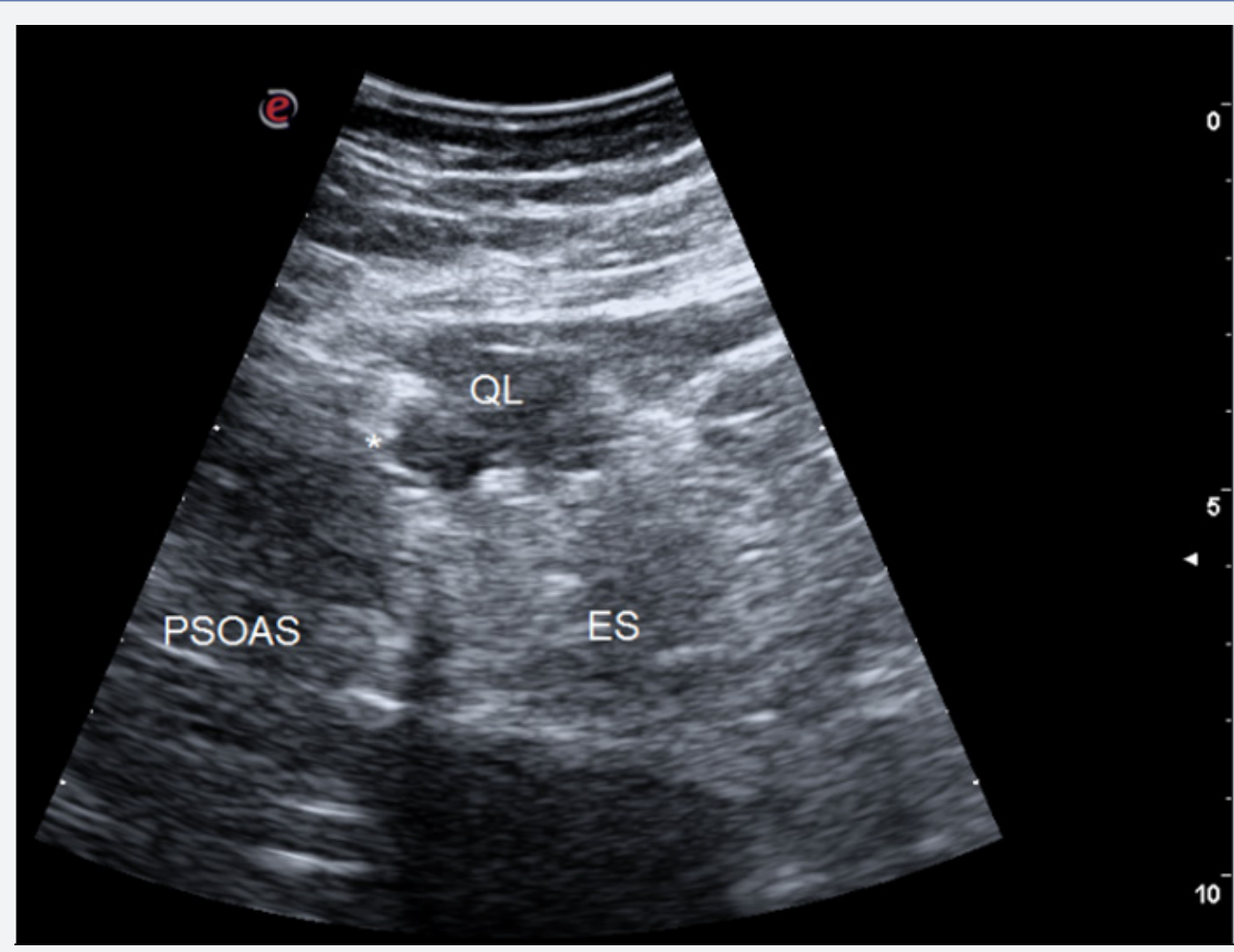

Figure 1: Ultrasonographic view of the quadratus lumborum muscle (QL), the psoas muscle (PSOAS) and the erector spinae muscle (ES). The target for injecting the local anesthetic and performing the quadratus lumborum block is marked with a star $\left(^{*}\right)$. 
On admission to the operatory room, the patient was monitored, and his vitals were: heart rate $70 \mathrm{bpm}$, radial artery blood pressure 150/80 mmHg and $\mathrm{SpO}_{2}$ 97\%. An intravenous line was started. The patient was then placed in left lateral recumbent position. After aseptic preparation, a transmuscular quadratus lumborum blockade (QLTM) was performed [1]. An ultrasound low frequency curvilinear probe was placed on patient's flank between the costal margin and the iliac crest to identify the tip of the transverse process (Figure 1). A 22-Gauge, 100mm long nerve block needle (Sonoplex, Pajunk, Germany) was then advanced with an 'in-plane' approach until the border of the quadratus lumborum muscle was reached; $30 \mathrm{ml}$ of $0.5 \%$ ropivacaine were then injected under ultrasound vision. Expansion of intermuscular plane due to local anaesthetic spread was observed.

The patient was then positioned back on supine position and a conscious sedation with propofol $1 \mathrm{mg} / \mathrm{kg} / \mathrm{h}$ and remifentanil $0.05 \mathrm{mcg} / \mathrm{kg} / \mathrm{min}$ was started. Thirty minutes after the nerve block the surgery started. Heart rate, blood pressure, and $\mathrm{SpO}_{2}$ were recorded perioperatively, and the vitals kept stable. The patient remained comfortable and spontaneously breathing throughout the surgery, which lasted for about 60 minutes. Additional local anesthetic infiltration with lidocaine $2 \%$ was required only during manipulation of the hernia sac, which contained an incarcerated but vital ileal segment, that didn't required resection. The postoperative course was uneventful, and the patient required only paracetamol administration for pain control. He was then discharged from the hospital on the fourth postoperative day.

Anaesthesia in very old and multi-morbid patients can be very challenging, even for minor surgery. Compared to younger patients, the elderly ones suffer from metabolic impairment, impaired wound-healing ability, higher sensibility to fluid overload and predisposition to complications and prolonged hospitalization [2]. Both general and regional anesthesia is associated with side effects in geriatric patients [3-5]. Mini-invasive surgery, lowimpact anesthesiological techniques and short hospital stays should be considered to decrease such complications.

In our opinion, QLTM emblematizes the best approach for inguinal hernioplasty in multi-morbid elderly patient, preserving both circulation and spontaneous breathing.

\section{Acknowledgments}

a. Assistance with the study: None.

b. Financial support and sponsorship: None.

c. Conflicts of interest: TT and ADC declare no competing interests; CO declares: Master engagement agreement speaking/consulting MSD Italia.

\section{References}

1. Børglum J, Moriggl B, Jensen K, Lønnqvist PA, Christensen AF, et al. (2013) Ultrasound-Guided Transmuscular Quadratus Lumborum Blockade. BJA 111(eLetters Supplement).

2. Walker M, Spivak M, Sebastian M (2014) The impact of aging physiology in critical care. Crit Care Nurs Clin North Am 26(1): 7-14.

3. Berggren D, Gustavsson Y, Eriksson B, Bucht G, Hansson LI, et al. (1987) Postoperative confusion after anesthesia in elderly patients with femoral neck fractures. Anesth Analg 66(6): 497-504.

4. Brown A, Visram A, Jones R, Irwin MG, Bacon-Shone J, et al. (1994) Preoperative and postoperative oxygen saturation in elderly following spinal or general anesthesia: an audit of current practice. Anaesth Intensive Care 22(2): 150-154.

5. Juelsgaard P, Sand NPR, Felsby S, Dalsgaard J, Jakobsen KB, et al. (1998) Perioperative myocardial ischaemia in patients undergoing surgery for fractured hip randomized to incremental spinal, single-dose spinal or general anaesthesia. Eur J Anaesthesiology 15(6): 656-663.

\section{Your next submission with Juniper Publishers will reach you the below assets}

- Quality Editorial service

- Swift Peer Review

- Reprints availability

- E-prints Service

- Manuscript Podcast for convenient understanding

- Global attainment for your research

- Manuscript accessibility in different formats

( Pdf, E-pub, Full Text, Audio)

- Unceasing customer service

Track the below URL for one-step submission https://juniperpublishers.com/online-submission.php 